\title{
Metabolic signals in sleep regulation: recent insights
}

This article was published in the following Dove Press journal:

Nature and Science of Sleep

5 January 2016

Number of times this article has been viewed

\section{Charu Shukla \\ Radhika Basheer \\ Department of Psychiatry, VA Boston Healthcare System, Harvard Medical School, West Roxbury, MA, USA}

Correspondence: Radhika Basheer Department of Psychiatry, VA Boston Healthcare System, Harvard Medical School, I 400 VFW Parkway, West Roxbury, MA 02132, USA

$\mathrm{Tel}+$ I 8572036 6I8I

Fax +I 8572035592

Email radhika_basheer@hms.harvard.edu
Abstract: Sleep and energy balance are essential for health. The two processes act in concert to regulate central and peripheral homeostasis. During sleep, energy is conserved due to suspended activity, movement, and sensory responses, and is redirected to restore and replenish proteins and their assemblies into cellular structures. During wakefulness, various energy-demanding activities lead to hunger. Thus, hunger promotes arousal, and subsequent feeding, followed by satiety that promotes sleep via changes in neuroendocrine or neuropeptide signals. These signals overlap with circuits of sleep-wakefulness, feeding, and energy expenditure. Here, we will briefly review the literature that describes the interplay between the circadian system, sleep-wake, and feeding-fasting cycles that are needed to maintain energy balance and a healthy metabolic profile. In doing so, we describe the neuroendocrine, hormonal/peptide signals that integrate sleep and feeding behavior with energy metabolism.

Keywords: sleep, energy balance, hypothalamus, metabolism, homeostasis

\section{Overview of the relationship between energy balance and sleep}

Sleep and energy balance are essential for health. The two processes act in concert to regulate central and peripheral homeostasis. Epidemiological and experimental evidence have linked insufficient sleep to metabolic disorders. ${ }^{1,2}$ During sleep, energy is conserved due to suspended activity, movement, and sensory responses, and is redirected to restore and replenish proteins and their assemblies into cellular structures. During wakefulness, various energy-demanding activities lead to hunger. Thus, hunger promotes arousal, and subsequent feeding, followed by satiety that promotes sleep via changes in neuroendocrine or neuropeptide signals. These signals overlap with circuits of sleep-wakefulness, feeding, and energy expenditure. A diurnal rhythm maintained by the internal circadian clock in response to the external environmental cues establishes rhythmicity of the physiological processes and hormonal release. These alterations are associated with the sleep-wake-state changes ${ }^{3,4}$ and the feeding-fasting cycles. ${ }^{5}$ Together, they maintain the energy balance that is critical for health. ${ }^{6}$ Disturbing one of the cycles often results in a cascade of effects, resulting in imbalance contributing to numerous metabolic disorders. Chronic circadian misalignments not only influence sleep but also influence several other systems including the immune system, ${ }^{7}$ appetitive hormones, and energy balance. ${ }^{8-10}$ Another promising evidence has emerged from the epidemiological studies using genome-wide associations revealing close linkage between sleep/circadian and metabolism-related genes. ${ }^{11,12}$ Thus, the circadian rhythmicity, sleep-wake, and feeding behavior are integral to bodily energy homeostasis. 
Here, we will briefly review the literature that describes the interplay between the circadian system, sleep-wake, and feeding-fasting cycles that are needed to maintain energy balance and a healthy metabolic profile (Figure 1). We will also describe the brain centers that integrate these three systems by regulating the autonomic and endocrine signals and discuss their functional interactions. The main focus of this article will be on the interaction between the neuronal and endocrine signals from the gastrointestinal tract and brown adipose tissue (BAT) to influence sleep-wake behavior and energy metabolism. Finally, we will review the causalities and the biological basis of the combined manifestations of sleep disturbances/disorders and briefly discuss the potential therapeutic perspectives.

\section{Interactive regulation of circadian, sleep, and feeding behavior}

Sleep/rest and wake/active behavioral states are observed in all living organisms. The state changes are assessed by recording the cortical electrical activity patterns using electroencephalogram (EEG) and skeletal muscle activity using electromyogram in mammals. Wakefulness is defined by low-voltage fast EEG activity and high muscle tone, whereas the non-rapid eye movement (NREM) sleep is defined by high-amplitude low-frequency EEG and decreased muscle tone, and rapid eye movement (REM) sleep is characterized by low-voltage fast EEG activity accompanied by complete loss of muscle tone. ${ }^{5}$ These assessments preclude sleep assessments in animals that do not have a well-defined cortex. However, researchers have proposed specific behavioral criteria to describe the presence of sleep-like states in several species of fish, reptiles, amphibians, and some invertebrates. ${ }^{13}$ One common

Circadian

control
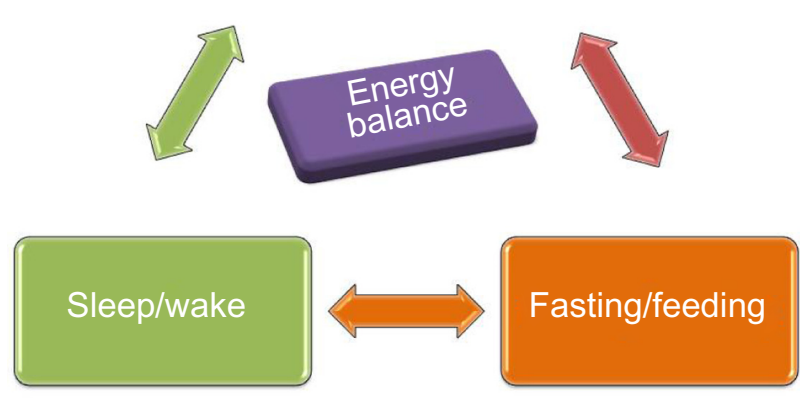

Figure I Bidirectional relationship between circadian clock, sleep-wake, and fastingfeeding behavior underlies maintenance of energy balance in the body. factor that remains constant across all species is the circadian rhythmicity in behavioral state changes.

Since the first description of the circadian "clock" (circadian locomotor output cycles kaput) gene in the suprachiasmatic nuclei $(\mathrm{SCN})$ within the brain, ${ }^{14}$ other clocks in the peripheral organs associated with energy regulation have been recognized that follow the master clock to maintain physiological rhythmicity. ${ }^{15}$ Homozygous clock mutant mice exhibit a significant increase in wakefulness by $\sim 2$ hours $/ 24$ hours independent of light-dark cues. ${ }^{16}$ These mice also show significantly attenuated diurnal feeding and locomotor rhythms, hyperphagia, and obesity. Most importantly, the mutant mice exhibit hyperglycemia accompanied by insufficient insulin production; a condition associated with type 2 diabetes in humans. ${ }^{17}$ These characteristics of clock mutant mice provide credence to the fundamental idea of the interactive manifestations of circadian rhythmicity, sleep-wake regulation, and feeding in order to maintain the physiological energy balance.

In the brain, the levels of the high energy molecule, adenosine triphosphate, exhibit a diurnal pattern with highest levels during sleep when the neuronal activity is decreased in the wake-associated areas. ${ }^{18}$ The hypothalamus serves as a multifunctional center regulating circadian, sleep, and feeding behaviors and also integrates central and peripheral neuroendocrine, endocrine, and peptide signals. The bodily homeostatic mechanisms and sleep homeostasis rely on the complex integrative activity of various neuronal subgroups within hypothalamus..$^{19}$ Anatomical studies further substantiated by lesion studies describe how the circadian center, the SCN, functionally connects to sleep and feeding centers within hypothalamus. The efferent projections from the SCN target the dorsal and ventral subparaventricular zone (SPZ) with a subset of the axons extending to the dorsomedial nucleus (DMH) in the hypothalamus. ${ }^{20}$ Thus, the ventral SPZ serves as a relay center and regulates rhythmicity in sleep and feeding as lesions in this area eliminate circadian rhythms of sleep-wakefulness, locomotor activity, and feeding. ${ }^{21,22}$ Although very few direct axonal inputs from SCN and ventral SPZ have been detected to the sleepregulating ventrolateral preoptic area (VLPO), a larger contingent of the axons project to the DMH. The DMH sends divergent efferents to the 1) sleep regulation center VLPO; 2) paraventricular nucleus $(\mathrm{PVN})$ containing the neurons synthesizing corticotropin-releasing hormone (CRH) and neurons that mediate preganglionic output to autonomous nervous system; and 3) lateral hypothalamus, an area that contains the hunger-stimulating and wakefulness-promoting 
peptide orexin (hypocretin) and melanin-concentrating hormone (Figure 2). ${ }^{19}$ The DMH also receives inputs from the arcuate nucleus, which is recognized for regulating food intake and energy expenditure by sensing the peripheral energy status through the "satiety hormone" leptin ${ }^{23}$ and the functionally opposite "hunger peptide" ghrelin. ${ }^{24}$ The ventromedial nucleus of the hypothalamus (VMH) lies close to the $\mathrm{DMH}$, arcuate nucleus, and third ventricle. It has no known neuroendocrine projections, but is directly involved in feeding behavior and regulating body weight. ${ }^{25,26}$ Lesions in the $\mathrm{VMH}$ region in rats lead to hyperphagia and weight gain. ${ }^{27}$ Brain-derived neurotrophic factor (BDNF) is a neurotrophin whose expression is regulated by signals from the melanocortin 4 receptor (MC4R) ${ }^{28}$ Compared with other brain regions, the expression of BDNF is most dense in the $\mathrm{VMH}$, and this region also mediates the ability of BDNF to increase energy expenditure. ${ }^{29}$ As BDNF regulates sleep onset (Table 1) along with hedonic food intake, this ventromedial hypothalamic region is likely to closely interact with the overlapping circuits of energy expenditure and sleep regulation. ${ }^{30,31}$ Thus, the hypothalamus is poised to serve as a center that integrates circadian, sleep-wake regulation, and feeding behavior (Figure 3).

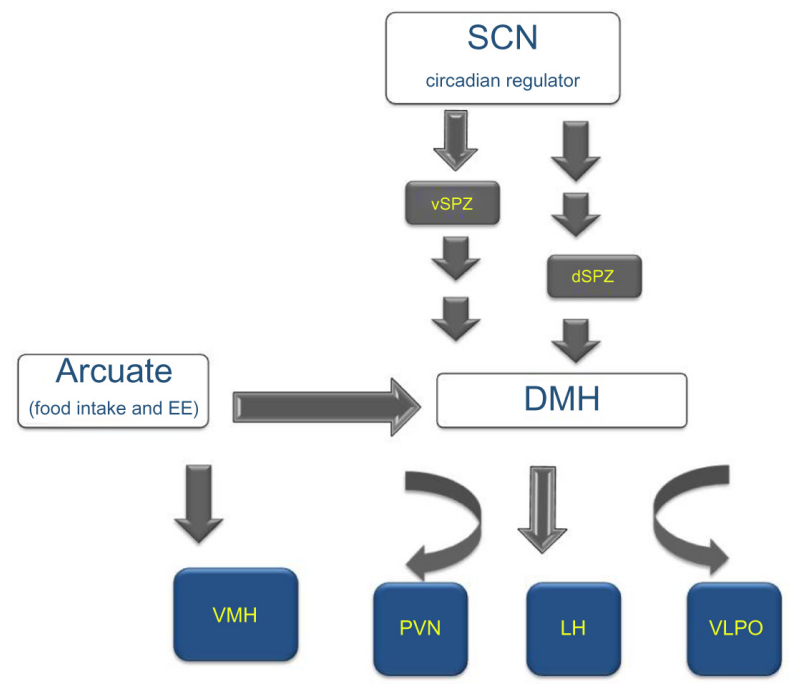

Figure 2 The neuronal connections between circadian, sleep, and feeding centers within the hypothalamus.

Notes: The efferent projections from suprachiasmatic nucleus ( $\mathrm{SCN}$ ) target the dorsal subparaventricular zone (dSPZ) and ventral subparaventricular zone (vSPZ) with a subset of the axons extending to the dorsomedial nucleus (DMH) in the hypothalamus. Few direct axonal inputs from SCN and ventral SPZ to the sleepregulating area of ventrolateral preoptic area (VLPO), and a larger contingent of the axons project to the dorsomedial hypothalamus (DMH). The DMH also receives inputs from the arcuate nucleus, which is recognized for regulating food intake and energy expenditure (EE) and sends projections to ventromedial hypothalamus $(\mathrm{VMH})$. The DMH sends divergent afferents to i) sleep regulation center VLPO, ii) paraventricular nucleus (PVN) containing the neurons synthesizing corticotropinreleasing hormone and neurons that mediate preganglionic output to autonomous nervous system, and iii) lateral hypothalamus (LH), an area that contains the hungerstimulating and wakefulness-promoting peptides.

\section{Neuronal and endocrine signals from the gastrointestinal tract involved in sleep regulation}

Multiple neuronal and endocrine signals have been identified for their direct or indirect roles in integrating sleep and energy balance via feeding mechanisms. Here, we describe the three most recognized peptides, orexin, leptin, and ghrelin, followed by a short summary of others that are included in Table 1.

Orexin is important for both sleep-wake regulation as well as feeding and energy balance. Mainly expressed in the perifornical region of the lateral hypothalamus, orexin exists in two forms, the neuropeptide orexin A (a 33 aminoacid peptide with two disulfide bonds) and orexin B (28 amino acid peptide) first described in $1998 .^{32,33}$ The orexin system has a wide distribution of cognate receptors extending its effects on central as well as peripheral targets, thereby regulating various physiological mechanisms such as feeding, energy metabolism, arousal, onset of REM, reward, and autonomic function. ${ }^{34-38}$ Clinical studies have underscored the importance of orexin signaling in human pathophysiology, as abnormalities in this system can lead to disorders such as narcolepsy, ${ }^{39}$ obstructive sleep apnea (OSA),${ }^{40}$ excessive daytime sleepiness secondary to traumatic brain injury, ${ }^{41}$ post-traumatic stress disorder, ${ }^{42}$ insomnia, and age-related changes in sleep and energy expenditure. ${ }^{43-45}$ The central administration of orexin dose-dependently increases food intake, waking time, motor activity, and metabolic rate, as well as heart rate and blood pressure in many species (reviewed in Siegel ${ }^{46}$ ). Ablations of the orexinergic system lead to sleep disturbances. In 1999, two seminal papers reported that the absence of orexinergic signaling, either due to orexin (peptide) gene knockout (KO) in mice $^{47}$ or due to orexin receptor 2 mutation in dogs ${ }^{48}$ results in elevated wake to rapid eye movement sleep (REMS) transitions, and increased REMS during the active period, mimicking narcolepsy in humans. Human narcoleptic subjects contain low levels of orexin in cerebrospinal fluid ${ }^{49,50}$ and exhibit loss of orexin neurons. ${ }^{39,51,52}$ In rats, lesioning orexin neurons also leads to a narcoleptic phenotype. ${ }^{53}$ Further evidence for the association between orexin neurons and wakefulness is provided from the experiments where selective optogenetic stimulation of orexin neurons reduced latency to wakefulness and increased sleep-to-wake transitions. ${ }^{54}$

Orexin is also known to link wake-state and feeding behavior. It activates overlapping neural substrates that modulate both arousal and feeding, thereby affecting energy homeostasis. Animal experiments have shown that 


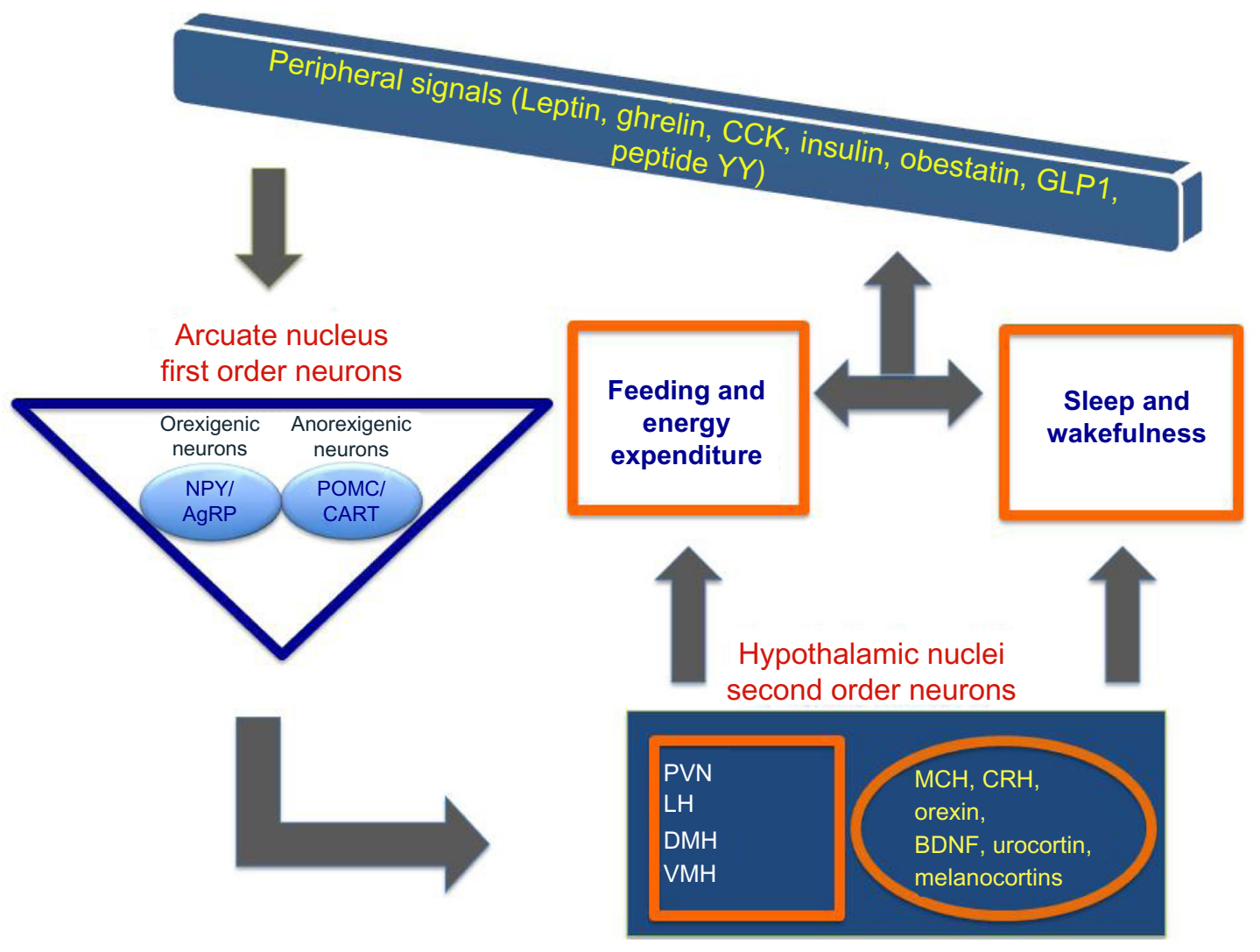

Figure 3 The interaction between peripheral and central signals regulating circadian, sleep, and feeding centers within hypothalamus.

Notes: The peripheral signals first act on the first-order neurons of the arcuate nucleus to release orexinergic or anorexinergic peptides, which in turn act on the secondorder neurons to regulate both sleep and feeding behavior. Finally, changes in the levels of these signals induced by sleep and feeding regulate the peripheral system.

Abbreviations: AgRP, agouti-related protein; BDNF, brain-derived neurotrophic factor; CART, cocaine- and amphetamine-regulated transcript; CRH, corticotropinreleasing hormone; DMH, dorsomedial nucleus; LH, lateral hypothalamus; $\mathrm{MCH}$, melanin-concentrating hormone; NPY, neuropeptide Y; POMC, proopiomelanocortin; PVN, paraventricular/nucleus; VMH, ventromedial hypothalamus; GLPI, glucagon like peptide I; CCK, Cholecystokinin.

intracerebral injections of orexin during the light (sleep) period induce feeding behavior in rodents as well as in zebrafishes. ${ }^{32,55,56} \mathrm{~A}$ study showed that orexin-deficient mice not only suffer from narcolepsy, but also exhibit metabolic imbalance and are obese due to decreased energy expenditure despite the concomitant reduction in feeding. ${ }^{43}$ Additionally, orexin neurons act as sensors of energy reserves; high extracellular glucose and leptin induce significant hyperpolarization whereas depleted glucose and ghrelin lead to depolarization of orexin neurons. ${ }^{57-59}$ The orexinergic (neuropeptide $\mathrm{Y}$, NPY and agouti-related protein [AgRP]) and anorexinergic (proopiomelanocortin cocaine- and amphetamine-regulated transcript) neurons innervate and regulate orexin neurons..$^{60,61}$ Thus, in concert with the other neuropeptides and hormones including melanin-concentrating hormone $(\mathrm{MCH})$ and $\mathrm{CRH}$ (Table 1 and Figure 3), the orexinergic system serves as an integral part of the hypothalamic neuronal network that regulates feeding behavior and energy homeostasis. ${ }^{62}$

In addition to orexin, two peptides from the peripheral system, leptin and ghrelin, have gained recognition for their opposing functions in the regulation of appetite, energy homeostasis, and sleep. ${ }^{63}$ Leptin, an anorectic peptide, is secreted primarily from white adipose tissue and acts on the arcuate nucleus to inhibit NPY/AgRP neurons, and activate the proopiomelanocortin (POMC)/cocaine- and amphetamine-regulated transcript neurons. Ghrelin, secreted by the stomach has an opposite function. In hypothalamus, orexin, leptin, and ghrelin are the key peptides that link sleep-wake behavior to energy homeostasis. The first-order neurons from arcuate nucleus send orexigenic/anorexigenic signals to neurons projecting not only to the lateral hypothalamus as described earlier, but also to other hypothalamic nuclei (Figure 3). A close association exists between the duration of sleep and the serum levels of leptin and ghrelin. Increasing sleep duration leads to an increase in leptin and a reciprocal decrease in ghrelin; the opposite is seen with short duration sleep. ${ }^{64-66}$ In controlled laboratory conditions, both acute ${ }^{67}$ and chronic partial sleep deprivation decrease serum leptin concentrations. ${ }^{68}$ This relationship is suggested to be the basis of increased body mass index (BMI) and obesity with 
Table I Central and peripheral signals involved in energy balance and sleep regulation

\begin{tabular}{|c|c|c|c|c|}
\hline \multirow[t]{2}{*}{ Hormone/neuropeptide } & \multirow[t]{2}{*}{ Site of synthesis } & \multicolumn{2}{|l|}{ Function } & \multirow[t]{2}{*}{ References } \\
\hline & & Energy metabolism & Sleep & \\
\hline Leptin & Adipose, Gl & $\begin{array}{l}\text { Decreases appetite, increases } \\
\text { energy expenditure }\end{array}$ & $\begin{array}{l}\text { During sleep deprivation, } \\
\text { decrease in leptin }\end{array}$ & 64,75 \\
\hline Ghrelin & GI & $\begin{array}{l}\text { Orexigenic, decreases energy } \\
\text { expenditure }\end{array}$ & $\begin{array}{l}\text { During sleep deprivation, } \\
\text { increase in ghrelin } \\
\text { Induces wakefulness }\end{array}$ & 63,137 \\
\hline Obestatin & GI & Decreases appetite & $\begin{array}{l}\text { Sleep-promoting effect triggers } \\
\text { NREM sleep and reduces SWA }\end{array}$ & 138,139 \\
\hline Cholecystokinin & GI & $\begin{array}{l}\text { Decreases appetite, energy } \\
\text { expenditure }\end{array}$ & Induces postprandial sleep & $|40,14|$ \\
\hline Glucagon like peptide I & GI & Decreases appetite & $\begin{array}{l}\text { Delayed satiety response after } \\
\text { sleep deprivation }\end{array}$ & $142, \mid 43$ \\
\hline Peptide YY & $\mathrm{Gl}$ & Decreases appetite & Elevated with sleep deprivation & 8,144 \\
\hline Neuromedin & Gl, brain & $\begin{array}{l}\text { Decreases appetite, increases } \\
\text { energy expenditure }\end{array}$ & $\begin{array}{l}\text { Sleep-wake architecture, } \\
\text { NREM-REM transitions }\end{array}$ & 145 \\
\hline Neuropeptide $Y$ & Hypothalamus & Anorexigenic & $\begin{array}{l}\text { Sleep onset, modulates REM, } \\
\text { sleep architecture }\end{array}$ & $146-149$ \\
\hline Agouti-related peptide & Hypothalamus & Anorexigenic & Sleep-wake regulation & 149,150 \\
\hline Proopiomelanocortin & Hypothalamus & Suppresses food intake & Sleep-wake regulation & $|49| 5 \mid, 152$, \\
\hline Orexin & Hypothalamus & Appetite stimulating & $\begin{array}{l}\text { Increases wakefulness, } \\
\text { suppresses REM }\end{array}$ & $47,153,154$ \\
\hline Thyrotropin-releasing hormone & Hypothalamus & Anorexigenic & Arousal & 149,155 \\
\hline Urocortin & Hypothalamus & $\begin{array}{l}\text { Anorexigenic, feeding and } \mathrm{EE} \\
\text { during stress }\end{array}$ & $\begin{array}{l}\text { Sleep-wake pattern } \\
\text { (wake, NREM) }\end{array}$ & 156,157 \\
\hline Brain-derived neurotrophic factor & Hypothalamus & Anorexigenic, hedonic food intake & Sleep onset & 30,31 \\
\hline Melanin-concentrating hormone & Hypothalamus & Orexigenic-appetite stimulating & Sleep-promoting effect & 158 \\
\hline Corticotropin-releasing hormone & Hypothalamus & $\begin{array}{l}\text { Anorexigenic, feeding and energy } \\
\text { expenditure during stress }\end{array}$ & $\begin{array}{l}\text { REM sleep, rebound sleep } \\
\text { following sleep deprivation }\end{array}$ & $157,159,160$ \\
\hline Glucocorticoids & Adrenal cortex & Feeding & $\begin{array}{l}\text { Elevated with sleep deprivation } \\
\text { and wakefulness }\end{array}$ & 161,162 \\
\hline
\end{tabular}

Abbreviations: GI, gastrointestinal; NREM, non-rapid eye movement; REM, rapid eye movement; EE, energy expenditure; SWA, slow wave activity.

sleep loss in humans ${ }^{64}$ The common sleep disorder, OSA, is associated with low ghrelin and elevated leptin levels, a condition also observed in obese individuals. ${ }^{69}$ Leptin is increasingly conceptualized as a biomarker for sleep disorders due to the close relationship between serum leptin levels and sleep durations; however, the topic is still debated due to some inconsistencies in the leptin levels reported in different studies. ${ }^{70}$ However, in narcoleptic patients with abnormal REMs and excessive daytime sleepiness, the mean 24-hour plasma leptin levels show a significant decrease with the loss of nocturnal acrophase. ${ }^{71}$ These observations, while establishing a relationship between the plasma levels of leptin or ghrelin with sleep and obesity, are not yet conclusive without a clear understanding of molecular regulations. The discovery of acyl ghrelin in stomach using reverse pharmacology is a noteworthy breakthrough. It is the only protein to be octanylated by ghrelin O-acyltransferase (GOAT). ${ }^{72}$ Due to this unique post-translational modification, inhibition of ghrelin O-acyltransferase may provide a critical molecular target in developing novel therapeutics for obesity and type 2 diabetes and is unlikely to affect the synthesis of other proteins.

There are several other mediators of metabolism as listed in Table 1 that regulate both energy metabolism and sleep. Sleep disorders such as OSA are linked to specific mutations in genes coding for neuroendocrine molecules or hormones. For example, a MC4R deficiency has been associated with OSA, and also with metabolic disorders along with obesity. ${ }^{73,74}$ The MC4R is expressed largely in the hypothalamus and is closely involved in appetite regulation, autonomic, and endocrine functions, as well as in insulin resistance. ${ }^{75,76}$

In humans, sleep loss has also been suggested to influence the choice of food, increasing preference for high-fat food facilitating weight gain. ${ }^{77,78}$ The feeding pattern and diet contents are also known to regulate the sleep quality and quantity due to the resulting influence on plasma levels of endocrine peptide. ${ }^{79}$ For example, a high-fat diet increases sleepiness in humans. ${ }^{80}$ Similarly, bariatric surgeries that impact the diet and associated endocrine factors can alter sleep in obese 
OSA patients. In a study of severely obese patients with OSA who underwent gastric bypass, the Epworth sleepiness score for the group fell from 14 (severe sleepiness) preoperatively to 5 (normal) at 1 month after surgery, a time when weight loss is expected to be just $10-12$ pounds. ${ }^{81}$ Although the association between sleep dysregulation, feeding, and energy metabolism is gaining much attention, the exact mechanisms and the interactions between various molecules need further investigation.

\section{Neuronal and endocrine signals from BAT involved in sleep regulation}

Known for its production of heat from uncoupling of mitochondrial oxidative phosphorylation, BAT is highly differentiated, and is uniquely characterized by the presence of uncoupling protein (UCP) 1 in large quantities. On activation, UCP1 allows rapid dissipation of chemical energy in the form of heat via the mitochondrial mechanism of maintaining proton flow across its inner membrane. ${ }^{82}$ The energy transfer and this direct conversion from food to heat are under the control of the sympathetic nervous system and the release of norepinephrine. Brown fat plays a critical role in maintaining metabolic homeostasis by regulating energy expenditure and glucose disposal. The acute ability of this tissue to generate heat by non-shivering thermogenesis has been the focus of many studies over the past decade for its possible homeostatic and thermoregulatory role in small mammals as well as in humans. ${ }^{83-86}$ Although white fat deposition increases with a defect in BAT in small animals, ${ }^{85}$ in humans, a higher BMI is associated with decreased BAT. ${ }^{87,88}$ It has been estimated that roughly $60 \mathrm{~g}$ of BAT can contribute up to $20 \%$ of total daily heat production in humans, ${ }^{89}$ implying an important functional role in temperature regulation. Although our understanding of the physiological and functional roles of BAT is still relatively limited, it is known that it can be rapidly activated by cold exposure ${ }^{90}$ and has a key role in overall energy balance regulation. ${ }^{91}$ Systems that regulate energy balance and have a homeostatic role are often linked to the neural circuits that modulate sleep and sleep quality. Here, we focus on the interaction of sleep and temperature regulation via BAT.

It has been reported that activated BAT generates sleeppromoting signals, which are essential for restorative sleep after a prolonged period of wakefulness. ${ }^{92}$ Sleep, particularly slow wave sleep, can be increased by specifically activating BAT thermogenesis. ${ }^{93}$ The importance of the role of UCP1 in thermoregulatory role of BAT is further established in the studies from UCP1 KO mice. In response to sleep deprivation, an elevated UCP1 mRNA expression is observed in BAT along with increased NREM, REM, and slow wave activity. ${ }^{92}$ Compared with wild type, the rebound changes that are characteristic of homeostatic sleep are significantly reduced in the UCP1 KO mice. ${ }^{92}$ Similarly, chronic sleep deprivation in rats upregulates UCP1 gene expression in BAT. ${ }^{94}$ Since UCP1 mediates heat production, these findings highlight the role of thermogenic activity of the BAT in increased sleep after sleep loss.

A number of neuroendocrine signals integrate to trigger these signals via BAT. Neuropeptides such as leptin, tumor necrosis factor, and interleukins 1 and 6 are present in adipose tissue and potentially carry sleep-promoting signals to the brain. ${ }^{95-97}$ However, the precise mechanism or a direct impact on the level of thermogenic effect in BAT is poorly understood. There is a close interaction between hypothalamic thermosensitivity and somnogenic mechanisms. ${ }^{98}$ The increase in core body temperature as a result of heat production from BAT and the brain can affect these hypothalamic systems, in turn altering sleep. For example, temperature-sensing transient receptor potential vanilloid 4 channels are also found in these adipose tissues and are highly sensitive to subtle changes in temperature. ${ }^{99,100}$ Additionally, extensive sensory afferent innervation links interscapular BAT extending to the hypothalamus including PVN, and to other areas such as periaqueductal gray, parabrachial nuclei, and raphe nuclei. ${ }^{101,102}$ There is evidence to suggest that these innervations are temperature sensitive and prevent excessive heating of the tissue by a negative feedback loop. ${ }^{103}$ Recent selective interscapular BAT deafferentation experiments in mice provide some evidence of significant sensory denervation in BAT; animals with disrupted innervation also show impaired recovery sleep response suggesting a neuronal regulation of sleep via BAT. ${ }^{92}$ The increase in sleep typically seen in ambient temperatures $\left(35^{\circ} \mathrm{C}\right)$ in wild-type mice is significantly diminished in the UCP1 KO mice in warmer environment, independent of differences in food intake and energy expenditure. ${ }^{92}$ Since increased lipolysis is a sleep-promoting signal, the impaired lipolytic response in UCP1-deficient mice could explain their sleep deficiency in the warm environment. However, there is a significant time lag between the sleep-promoting and temperature effects of BAT activation, suggesting that an enhancement of sleep is not due to elevated body temperature. ${ }^{104}$ Together, these findings indicate the role of metabolic activity of BAT, which in turn works in cohesion with promoting optimal sleep. 
Most research on establishing the link between obesity and sleep has focused on OSA. Significant weight loss and reduction in BAT has been reported in a rat model of sleep apnea, ${ }^{105}$ while a reduction in UCP1 expression in BAT was seen in a mouse model of OSA. ${ }^{106}$ Reduced function of the orexin system resulting in the disordered sleep patterns of narcolepsy is also characterized by disruptions in thermoregulation and in energy homeostasis, along with obesity propensity. ${ }^{107-109}$ In rats, neuronal activation of orexin projections from the perifornical lateral hypothalamus increases BAT thermogenesis, indicating that orexin could significantly mediate the overall tone of BAT thermogenesis, thereby regulating body temperature during sleep and wakefulness. ${ }^{110,111}$ Impaired BAT function is a possible common link between inadequate sleep and metabolic disorders. Overall, metabolic status is tightly regulated by a complex signaling mechanism, which also adjusts the sleep-wake activity in order to maintain constant homeostasis. Feeding signals and others related to metabolism, activity, and thermoregulation interact with sleep circuits. Signals arising from BAT are part of this signaling mechanism and are likely to alter sleep and wakefulness.

\section{Integration of metabolic signals with sleep regulation: neurobiology and neurochemistry}

The homeostatic regulatory system works in close association with the peripheral metabolic signals to modulate energy balance. The central orexinergic and anorexinergic molecules such as NPY, orexin, histamine, cholecystokinin, and CRH influence the sympathetic activity to intercapsular BAT. ${ }^{112-118}$ Similarly, the circulating hormones that act as signals of energy surplus or surfeit activate hypothalamic neuronal populations that regulate sleep homeostasis. ${ }^{113}$ The central melanocortin system is important in sensing and interacting with peripheral, neural, and endocrine cues such as insulin, leptin, and ghrelin, which then influence downstream mediators of energy balance. ${ }^{76,113}$

Along with their established role in altering appetite and energy utilization, these neuronal and endocrine signals also interact with sleep-wake behavior. Further, their cyclical high/low profiles are often well synchronized with the sleepwake timing within a 24-hour period. Several recent studies have revealed that the bodily energy balance maintained by such synchronized systems is disturbed by changing the sleep-wake durations and timing within the 24-hour period. The major impact of shorter sleep durations on the feeding and energy imbalance leads to higher incidences of insulin resistance, glucose intolerance, and result in metabolic syndrome. ${ }^{14,115}$ The quality of sleep is also an important factor in maintaining energy balance. Sufficient slow wave sleep is needed to trigger a number of peripheral and central effects such as release of growth hormone and prolactin, and inhibiting corticotropic and thyrotropic activity which in turn regulate blood pressure, heart rate, and sympathetic nerve activity. ${ }^{115,119}$

Deficiencies in sleep are associated with obesity, yet little is known about how chronic sleep restriction influences energy expenditure. There is substantial literature to suggest that there are changes in satiety and hunger hormones during sleep loss; however, the mechanisms by which sleep loss contributes to weight gain are likely to be more complex. ${ }^{120,121}$ In a report from human subjects in which the effect of 5 days of reduced sleep was investigated, significant weight gain was observed in spite of changes in the levels of ghrelin, leptin, and peptide YY that signal excess energy stores suggestive of decreased sensitivity to the satiety hormones during sleep loss. ${ }^{8}$

An elevated food demand is likely to be a physiological adaptation to provide the resources to sustain prolonged wakefulness during sleep loss. However, in the current obesogenic environment, weight gain is plausible because energy intake is in excess of the required energy demands during sleep loss. This could be because sleep loss can alter brain mechanisms involved in non-homeostatic food intake (eg, mood, comfort, reward, and reduced eating restraint). ${ }^{77,114,122} \mathrm{~A}$ recent study in humans using functional magnetic resonance imaging and food-desire tasks demonstrated that the brain regions affected by sleep loss also affect appetitive food desire and enhance the response to hedonic food. ${ }^{77,122}$ They confirm that lack of sleep diminishes activity in appetite evaluation centers in the brain and further triggers an increase in craving for a high-calorie diet. ${ }^{77}$ Sleep loss also consistently increases food intake in humans, mainly at night. Sleep and circadian systems are highly integrated; lack of sleep also leads to a delay in circadian timing and thus a change in the circadian timing of meals, especially breakfast. ${ }^{123,124} \mathrm{~A}$ recent Drosophila study involving timerestricted feeding showed a direct effect on caloric intake, sleep quality, and cardiovascular profile to further indicate this interesting interplay between circadian cycle, feedingfasting, and the overall metabolic health. ${ }^{125}$ These reports strongly implicate the circadian periodicity of metabolic pathways in sleep loss-related weight gain.

A study comparing sleep deprivation (4 hours/2 nights) vs sleep extension (10 hours/2 nights) reported a panel of endocrine changes that indicate metabolic imbalance. The 
individuals with sleep debt were found to have lower morning insulin levels, higher glucose, elevated ghrelin-to-leptin ratio, and an increase in appetite for high carbohydrate food. ${ }^{65}$ Other reports including a large population study show a direct link between circulating leptin and ghrelin levels with sleep restriction. ${ }^{64,126}$ In general, curtailed sleep is accompanied by elevated cortisol during the day. ${ }^{115}$ Chronic lack of sleep is also associated with an aberrant carbohydrate tolerance and impaired glucose tolerance, thus increasing the risk for type 2 diabetes. Central and peripheral alterations due to excessive glucocorticoids may contribute to aging and related deficits in memory. ${ }^{127,128}$ Figure 3 shows the key mediators of these pathways and their integration at the central nervous system having a direct two-way communication with sleep and metabolic parameters. Thus, sleep duration has a multitude of effects on both endocrine and metabolic functions, and the neuroendocrine regulation of appetite and food consumption is altered by sleep restriction and may favor the development of obesity.

\section{Therapeutic perspectives: potential pharmacological targets for the treatment of sleep disorders, especially those linked to obesity and metabolic disorders}

It is widely recognized that short sleep duration is associated with elevated BMI in many epidemiological studies. As discussed earlier, several pathways link sleep deprivation to energy imbalance, including increased food intake, decreased energy expenditure, and changes in levels of appetite-regulating hormones including leptin and ghrelin. One cannot ignore the contribution of multimedia (eg, television viewing, computer, and Internet), which aggravates sedentary behavior and increases caloric intake. Electronic devices including e-Readers have been recently shown to directly affect circadian cycle and alter sleep and alertness, the following day. ${ }^{129}$ In addition, shift-work, long working hours, and increased time commuting to and from work can contribute to obesity and related metabolic disorders, because of their strong link to shorter sleep times. Consequently, the first and foremost consideration in treating the metabolic disorders is the evaluation of the life style and its potential impact on energy imbalance.

The hormone melatonin, normally secreted from the pineal gland at night, serves as the signal of darkness in the organism and plays a pivotal role in the physiological regulation of circadian rhythms, including sleep. There is a growing body of evidence suggesting a link between disturbances in melatonin production and impaired insulin, glucose, lipid metabolism, and antioxidant capacity. ${ }^{130,131}$ Several studies support that melatonin can prevent hyperadiposity in animal models of obesity. In obese rats, melatonin treatment ameliorated abdominal obesity, hyperinsulinemia, hypercholesterolemia, hyperglycemia, hyperbetalipoproteinemia, and glycosuria. ${ }^{132}$ Melatonin is one of the several system targets for sleep disorders. Ramelteon is a selective melatonin receptor type 1 (MT1) and melatonin receptor type 2 (MT2) receptors agonist and is commonly used for insomnia. ${ }^{133}$ However, no published studies have systematically evaluated its effects on metabolic pathways. Sleep aids directed toward $\mathrm{GABA}_{\mathrm{A}}$ receptors, such as zolpidem, eszopiclone, and zaleplon, are commonly used despite a paucity of published reports on the drug's effects on metabolic processes. However, the orexin peptides and their receptors, by virtue of their involvement in multiple physiological processes such as the regulation of sleep/wakefulness state, and energy homeostasis are proving to be good targets for drug development. The use of small-molecule orexin receptor antagonists as novel therapies for the treatment of insomnia is increasingly being discussed. ${ }^{134}$ Recently, a dual receptor antagonist, suvorexant was approved by the US Food and Drug Administration for treating insomnia and is being marketed by Merck Pharmaceuticals as Belsomra. ${ }^{135,136}$ Increased levels of signaling via the orexin peptide/receptor system enhance sleep and may protect against obesity. Thus, orexin agonists and antagonists are thought to be promising avenues toward the treatment of sleep disorders as well as for targeting eating disorders.

In summary, epidemiological studies and empirical evidence from well-crafted human and animal experiments have begun to converge upon the close association between sleep-wake and feeding-fasting cycles that maintain energy balance. The hypothalamus is increasingly being recognized for its unifying role in maintaining energy balance. Research continues to explore and understand neuropeptide-specific populations within hypothalamus, their connectivity and their selective contributions that will allow identification of precise therapeutic targets for combined treatment of sleep and metabolic imbalances.

\section{Acknowledgments}

This work was supported by the Department of Veterans Affairs Medical Research Service Merit Award, NINDS 079866, and NIMH 39683. We would like to thank Dr Colleen $\mathrm{M}$ Novak for critically reading this review. 


\section{Disclosure}

The authors report no conflicts of interest in this work.

\section{References}

1. Reutrakul S, Van Cauter E. Interactions between sleep, circadian function, and glucose metabolism: implications for risk and severity of diabetes. Ann NY Acad Sci. 2014;1311:151-173.

2. Kim TW, Jeong JH, Hong SC. The impact of sleep and circadian disturbance on hormones and metabolism. Int J Endocrinol. 2015; 2015:591729.

3. Czeisler CA, Klerman EB. Circadian and sleep-dependent regulation of hormone release in humans. Recent Prog Hormone Res. 1999;54: 97-130; discussion 130-132.

4. Dijk DJ, Lockley SW. Integration of human sleep-wake regulation and circadian rhythmicity. J Appl Physiol. 2002;92(2):852-862.

5. Brown RE, Basheer R, McKenna JT, Strecker RE, McCarley RW. Control of sleep and wakefulness. Physiol Rev. 2012;92(3): 1087-1187.

6. Laposky AD, Bass J, Kohsaka A, Turek FW. Sleep and circadian rhythms: key components in the regulation of energy metabolism. FEBS Lett. 2008;582(1):142-151.

7. Wright KP Jr, Drake AL, Frey DJ, et al. Influence of sleep deprivation and circadian misalignment on cortisol, inflammatory markers, and cytokine balance. Brain BehavImmun. 2015;47:24-34.

8. Markwald RR, Melanson EL, Smith MR, et al. Impact of insufficient sleep on total daily energy expenditure, food intake, and weight gain. Proc Natl Acad Sci U S A. 2013;110(14):5695-5700.

9. McHill AW, Melanson EL, Higgins J, et al. Impact of circadian misalignment on energy metabolism during simulated nightshift work. Proc Natl Acad Sci U S A. 2014;111(48):17302-17307.

10. Nguyen J, Wright KP Jr. Influence of weeks of circadian misalignment on leptin levels. Nat Sci Sleep. 2010;2:9-18.

11. Locke AE, Kahali B, Berndt SI, et al. Genetic studies of body mass index yield new insights for obesity biology. Nature. 2015;518(7538): 197-206.

12. Shungin D, Winkler TW, Croteau-Chonka DC, et al. New genetic loci link adipose and insulin biology to body fat distribution. Nature. 2015;518(7538):187-196.

13. Campbell SS, Tobler I. Animal sleep: a review of sleep duration across phylogeny. Neurosci Biobehav Rev. 1984;8(3):269-300.

14. King DP, Zhao Y, Sangoram AM, et al. Positional cloning of the mouse circadian clock gene. Cell. 1997;89(4):641-653.

15. Reppert SM, Weaver DR. Coordination of circadian timing in mammals. Nature. 2002;418(6901):935-941.

16. Naylor E, Bergmann BM, Krauski K, et al. The circadian clock mutation alters sleep homeostasis in the mouse. $J$ Neurosci. 2000;20(21): 8138-8143.

17. Turek FW, Joshu C, Kohsaka A, et al. Obesity and metabolic syndrome in circadian Clock mutant mice. Science (New York, NY). 2005;308(5724):1043-1045.

18. Dworak M, McCarley RW, Kim T, Kalinchuk AV, Basheer R. Sleep and brain energy levels: ATP changes during sleep. J Neurosci. 2010;30(26): 9007-9016.

19. Saper CB. Staying awake for dinner: hypothalamic integration of sleep, feeding, and circadian rhythms. Prog Brain Res. 2006;153:243-252.

20. Chou TC, Scammell TE, Gooley JJ, Gaus SE, Saper CB, Lu J. Critical role of dorsomedial hypothalamic nucleus in a wide range of behavioral circadian rhythms. J Neurosci. 2003;23(33):10691-10702.

21. Abrahamson EE, Moore RY. Lesions of suprachiasmatic nucleus efferents selectively affect rest-activity rhythm. Mol Cell Endocrinol. 2006;252(1-2):46-56.

22. Lu J, Zhang YH, Chou TC, et al. Contrasting effects of ibotenate lesions of the paraventricular nucleus and subparaventricular zone on sleep-wake cycle and temperature regulation. J Neurosci. 2001;21(13): 4864-4874.
23. Houseknecht KL, Baile CA, Matteri RL, Spurlock ME. The biology of leptin: a review. J Anim Sci. 1998;76(5):1405-1420.

24. Kojima M, Kangawa K. Ghrelin: structure and function. Physiol Rev. 2005;85(2):495-522.

25. Millington GW, Tung YC, Hewson AK, O'Rahilly S, Dickson SL. Differential effects of alpha-, beta- and gamma(2)-melanocytestimulating hormones on hypothalamic neuronal activation and feeding in the fasted rat. Neuroscience. 2001;108(3):437-445.

26. Satoh N, Ogawa Y, Katsuura G, et al. Pathophysiological significance of the obese gene product, leptin, in ventromedial hypothalamus (VMH)lesioned rats: evidence for loss of its satiety effect in VMH-lesioned rats. Endocrinology. 1997;138(3):947-954.

27. Grundmann SJ, Pankey EA, Cook MM, Wood AL, Rollins BL, King BM. Combination unilateral amygdaloid and ventromedial hypothalamic lesions: evidence for a feeding pathway. Am J Physiol Regul Integr Comp Physiol. 2005;288(3):R702-R707.

28. Xu B, Goulding EH, Zang K, et al. Brain-derived neurotrophic factor regulates energy balance downstream of melanocortin-4 receptor. Nat Neurosci. 2003;6(7):736-742.

29. Wang C, Bomberg E, Billington CJ, Levine AS, Kotz CM. Brain-derived neurotrophic factor (BDNF) in the hypothalamic ventromedial nucleus increases energy expenditure. Brain Res. 2010;1336:66-77.

30. Faraguna U, Vyazovskiy VV, Nelson AB, Tononi G, Cirelli C. A causal role for brain-derived neurotrophic factor in the homeostatic regulation of sleep. J Neurosci. 2008;28(15):4088-4095.

31. Rios M. New insights into the mechanisms underlying the effects of BDNF on eating behavior. Neuropsychopharmacology. 2011;36(1):368-369.

32. Sakurai T, Amemiya A, Ishii M, et al. Orexins and orexin receptors: a family of hypothalamic neuropeptides and $\mathrm{G}$ protein-coupled receptors that regulate feeding behavior. Cell. 1998;92(4):573-585.

33. de Lecea L, KilduffTS, Peyron C, et al. The hypocretins: hypothalamusspecific peptides with neuroexcitatory activity. Proc Natl Acad Sci US A. 1998;95(1):322-327.

34. Burdakov D, Karnani MM, Gonzalez A. Lateral hypothalamus as a sensor-regulator in respiratory and metabolic control. Physiol Behav. 2013;121:117-124.

35. de Lecea L, Huerta R. Hypocretin (orexin) regulation of sleep-to-wake transitions. Front Pharmacol. 2014;5:16.

36. Karnani M, Burdakov D. Multiple hypothalamic circuits sense and regulate glucose levels. Am J Physiol Regul Integr Comp Physiol. 2011;300(1):R47-R55.

37. Mahler SV, Smith RJ, Moorman DE, Sartor GC, Aston-Jones G. Multiple roles for orexin/hypocretin in addiction. Prog Brain Res. 2012;198:79-121.

38. Nixon JP, Mavanji V, Butterick TA, Billington CJ, Kotz CM, Teske JA. Sleep disorders, obesity, and aging: the role of orexin. Ageing Res Rev. 2015;20:63-73.

39. Peyron C, Faraco J, Rogers W, et al. A mutation in a case of early onset narcolepsy and a generalized absence of hypocretin peptides in human narcoleptic brains. Nat Med. 2000;6(9):991-997.

40. Ahmed WA, Tsutsumi M, Nakata S, et al. A functional variation in the hypocretin neuropeptide precursor gene may be associated with obstructive sleep apnea syndrome in Japan. Laryngoscope. 2012;122(4):925-929.

41. Baumann CR. Traumatic brain injury and disturbed sleep and wakefulness. Neuromolecular Med. 2012;14(3):205-212.

42. Strawn JR, Pyne-Geithman GJ, Ekhator NN, et al. Low cerebrospinal fluid and plasma orexin-A (hypocretin-1) concentrations in combatrelated posttraumatic stress disorder. Psychoneuroendocrinology. 2010;35(7):1001-1007.

43. Hara J, Beuckmann CT, Nambu T, et al. Genetic ablation of orexin neurons in mice results in narcolepsy, hypophagia, and obesity. Neuron. 2001;30(2):345-354.

44. Fadel JR, Jolivalt CG, Reagan LP. Food for thought: the role of appetitive peptides in age-related cognitive decline. Ageing Res Rev. 2013;12(3):764-776. 
45. Fronczek R, Baumann CR, Lammers GJ, Bassetti CL, Overeem S. Hypocretin/orexin disturbances in neurological disorders. Sleep Med Rev. 2009;13(1):9-22.

46. Siegel JM. Hypocretin (orexin): role in normal behavior and neuropathology. Annu Rev Psychol. 2004;55:125-148.

47. Chemelli RM, Willie JT, Sinton CM, et al. Narcolepsy in orexin knockout mice: molecular genetics of sleep regulation. Cell. 1999;98(4): $437-451$.

48. Lin L, Faraco J, Li R, et al. The sleep disorder canine narcolepsy is caused by a mutation in the hypocretin (orexin) receptor 2 gene. Cell. 1999;98(3):365-376.

49. Mignot E, Lammers GJ, Ripley B, et al. The role of cerebrospinal fluid hypocretin measurement in the diagnosis of narcolepsy and other hypersomnias. Arch Neurol. 2002;59(10):1553-1562.

50. Nishino S, Ripley B, Overeem S, Lammers GJ, Mignot E. Hypocretin (orexin) deficiency in human narcolepsy. Lancet. 2000;355(9197): 39-40.

51. Thannickal TC, Moore RY, Nienhuis R, et al. Reduced number of hypocretin neurons in human narcolepsy. Neuron. 2000;27(3):469-474.

52. Crocker A, Espana RA, Papadopoulou M, et al. Concomitant loss of dynorphin, NARP, and orexin in narcolepsy. Neurology. 2005;65(8): 1184-1188.

53. Gerashchenko D, Blanco-Centurion C, Greco MA, Shiromani PJ. Effects of lateral hypothalamic lesion with the neurotoxin hypocretin2-saporin on sleep in Long-Evans rats. Neuroscience. 2003;116(1): 223-235.

54. Adamantidis AR, Zhang F, Aravanis AM, Deisseroth K, de Lecea L. Neural substrates of awakening probed with optogenetic control of hypocretin neurons. Nature. 2007;450(7168):420-424.

55. Yokobori E, Kojima K, Azuma M, et al. Stimulatory effect of intracerebroventricular administration of orexin A on food intake in the zebrafish, Danio rerio. Peptides. 2011;32(7):1357-1362.

56. Haynes AC, Jackson B, Overend P, et al. Effects of single and chronic intracerebroventricular administration of the orexins on feeding in the rat. Peptides. 1999;20(9):1099-1105.

57. Burdakov D, Gerasimenko O, Verkhratsky A. Physiological changes in glucose differentially modulate the excitability of hypothalamic melanin-concentrating hormone and orexin neurons in situ. J Neurosci. 2005;25(9):2429-2433.

58. Gonzalez JA, Jensen LT, Doyle SE, et al. Deletion of TASK1 and TASK 3 channels disrupts intrinsic excitability but does not abolish glucose or $\mathrm{pH}$ responses of orexin/hypocretin neurons. Eur J Neurosci. 2009;30(1):57-64.

59. Schone C, Venner A, Knowles D, Karnani MM, Burdakov D. Dichotomous cellular properties of mouse orexin/hypocretin neurons. J Physiol. 2011;589(Pt 11):2767-2779.

60. Zheng H, Corkern MM, Crousillac SM, Patterson LM, Phifer CB, Berthoud HR. Neurochemical phenotype of hypothalamic neurons showing Fos expression $23 \mathrm{~h}$ after intracranial AgRP. Am J Physiol Regul Integr Comp Physiol. 2002;282(6):R1773-R1781.

61. Elias CF, Saper CB, Maratos-Flier E, et al. Chemically defined projections linking the mediobasal hypothalamus and the lateral hypothalamic area. J Comp Neurol. 1998;402(4):442-459.

62. Novak CM, Levine JA. Central neural and endocrine mechanisms of non-exercise activity thermogenesis and their potential impact on obesity. J Neuroendocrinol. 2007;19(12):923-940.

63. Shintani M, Ogawa Y, Ebihara K, et al. Ghrelin, an endogenous growth hormone secretagogue, is a novel orexigenic peptide that antagonizes leptin action through the activation of hypothalamic neuropeptide $\mathrm{Y} /$ Y1 receptor pathway. Diabetes. 2001;50(2):227-232.

64. Taheri S, Lin L, Austin D, Young T, Mignot E. Short sleep duration is associated with reduced leptin, elevated ghrelin, and increased body mass index. PLoS Med. 2004;1(3):e62.

65. Spiegel K, Tasali E, Penev P, Van Cauter E. Brief communication: sleep curtailment in healthy young men is associated with decreased leptin levels, elevated ghrelin levels, and increased hunger and appetite. Ann Intern Med. 2004;141(11):846-850.
66. Littman AJ, Vitiello MV, Foster-Schubert K, et al. Sleep, ghrelin, leptin and changes in body weight during a 1-year moderate-intensity physical activity intervention. Int $J$ Obes. 2007;31(3):466-475.

67. Mullington JM, Chan JL, Van Dongen HP, et al. Sleep loss reduces diurnal rhythm amplitude of leptin in healthy men. J Neuroendocrinol. 2003;15(9):851-854.

68. Spiegel K, Leproult R, Van Cauter E. [Impact of sleep debt on physiological rhythms]. Rev Neurol. 2003;159(11 Suppl):6S11-16S20.

69. Harsch IA, Konturek PC, Koebnick C, et al. Leptin and ghrelin levels in patients with obstructive sleep apnoea: effect of CPAP treatment. Eur Respir J. 2003;22(2):251-257.

70. Pan W, Kastin AJ. Leptin: a biomarker for sleep disorders? Sleep Med Rev. 2014;18(3):283-290.

71. Kok SW, Meinders AE, Overeem S, et al. Reduction of plasma leptin levels and loss of its circadian rhythmicity in hypocretin (orexin)-deficient narcoleptic humans. J Clin Endocrinol Metab. 2002;87(2):805-809.

72. Yang J, Zhao TJ, Goldstein JL, Brown MS. Inhibition of ghrelin O-acyltransferase (GOAT) by octanoylated pentapeptides. Proc Natl Acad Sci U S A. 2008;105(31):10750-10755.

73. Loos RJ, Lindgren CM, Li S, et al. Common variants near MC4R are associated with fat mass, weight and risk of obesity. Nat Genet. 2008;40(6):768-775.

74. Pillai S, Nandalike K, Kogelman Y, Muzumdar R, Balk SJ, Arens R. Severe obstructive sleep apnea in a child with melanocortin-4 receptor deficiency. J Clin Sleep Med. 2014;10(1):99-101.

75. Elmquist JK, Elias CF, Saper CB. From lesions to leptin: hypothalamic control of food intake and body weight. Neuron. 1999;22(2): 221-232.

76. Cowley MA, Pronchuk N, Fan W, Dinulescu DM, Colmers WF, Cone RD. Integration of NPY, AGRP, and melanocortin signals in the hypothalamic paraventricular nucleus: evidence of a cellular basis for the adipostat. Neuron. 1999;24(1):155-163.

77. Greer SM, Goldstein AN, Walker MP. The impact of sleep deprivation on food desire in the human brain. Nat Commun. 2013;4:2259.

78. Dinges DF, Chugh D. Physiologic correlates of sleep deprivation. In: Kinney JM, Tucker HN, eds. Physiology, stress and malnutrition: Functional correlates, nutritional intervention. New York:Lippincott-Raven, 1997:1-27.

79. Panossian LA, Veasey SC. Daytime sleepiness in obesity: mechanisms beyond obstructive sleep apnea-a review. Sleep. 2012;35(5): 605-615.

80. Wells AS, Read NW, Uvnas-Moberg K, Alster P. Influences of fat and carbohydrate on postprandial sleepiness, mood, and hormones. Physiol Behav. 1997;61(5):679-686.

81. Varela JE, Hinojosa MW, Nguyen NT. Resolution of obstructive sleep apnea after laparoscopic gastric bypass. Obes Surg. 2007;17(10): 1279-1282.

82. Cannon B, Nedergaard J. Brown adipose tissue: function and physiological significance. Physiol Rev. 2004;84(1):277-359.

83. Nedergaard J, Bengtsson T, Cannon B. Unexpected evidence for active brown adipose tissue in adult humans. Am J Physiol Endocrinol Metab. 2007;293(2):E444-E452.

84. Blessing W, Mohammed M, Ootsuka Y. Heating and eating: brown adipose tissue thermogenesis precedes food ingestion as part of the ultradian basic rest-activity cycle in rats. Physiol Behav. 2012;105(4): 966-974.

85. Hamann A, Flier JS, Lowell BB. Decreased brown fat markedly enhances susceptibility to diet-induced obesity, diabetes, and hyperlipidemia. Endocrinology. 1996;137(1):21-29.

86. Symonds ME, Pope M, Sharkey D, Budge H. Adipose tissue and fetal programming. Diabetologia. 2012;55(6):1597-1606.

87. Vijgen GH, Bouvy ND, Teule GJ, et al. Increase in brown adipose tissue activity after weight loss in morbidly obese subjects. J Clin Endocrinol Metab. 2012;97(7):E1229-E1233.

88. Vijgen GH, Bouvy ND, Teule GJ, Brans B, Schrauwen P, van Marken Lichtenbelt WD. Brown adipose tissue in morbidly obese subjects. PLoS One. 2011;6(2):e17247. 
89. Ouellet V, Labbe SM, Blondin DP, et al. Brown adipose tissue oxidative metabolism contributes to energy expenditure during acute cold exposure in humans. J Clin Investig. 2012;122(2):545-552.

90. Symonds ME, Henderson K, Elvidge L, et al. Thermal imaging to assess age-related changes of skin temperature within the supraclavicular region co-locating with brown adipose tissue in healthy children. $J$ Pediatrics. 2012;161(5):892-898.

91. van Marken Lichtenbelt WD, Schrauwen P. Implications of nonshivering thermogenesis for energy balance regulation in humans. Am J Physiol Regul Integr Comp Physiol. 2011;301(2):R285-R296.

92. Szentirmai E, Kapas L. Intact brown adipose tissue thermogenesis is required for restorative sleep responses after sleep loss. Eur J Neurosci. 2014;39(6):984-998.

93. Dewasmes G, Loos N, Delanaud S, Dewasmes D, Geloen A. Activation of brown adipose tissue thermogenesis increases slow wave sleep in rat. Neurosci Lett. 2003;339(3):207-210.

94. Koban M, Swinson KL. Chronic REM-sleep deprivation of rats elevates metabolic rate and increases UCP1 gene expression in brown adipose tissue. Am J Physiol Endocrinol Metab. 2005;289(1):E68-E74.

95. Kapas L, Hong L, Cady AB, et al. Somnogenic, pyrogenic, and anorectic activities of tumor necrosis factor-alpha and TNF-alpha fragments. Am J Physiol. 1992;263(3 Pt 2):R708-R715.

96. Sinton CM, Fitch TE, Gershenfeld HK. The effects of leptin on REM sleep and slow wave delta in rats are reversed by food deprivation. J Sleep Res. 1999;8(3):197-203.

97. Hogan D, Morrow JD, Smith EM, Opp MR. Interleukin-6 alters sleep of rats. J Neuroimmunol. 2003;137(1-2):59-66.

98. McGinty D, Szymusiak R. Hypothalamic regulation of sleep and arousal. Front Biosci. 2003;8:s1074-s1083.

99. Ye L, Kleiner S, Wu J, et al. TRPV4 is a regulator of adipose oxidative metabolism, inflammation, and energy homeostasis. Cell. 2012;151(1): 96-110.

100. Watanabe H, Vriens J, Suh SH, Benham CD, Droogmans G, Nilius B. Heat-evoked activation of TRPV4 channels in a HEK293 cell expression system and in native mouse aorta endothelial cells. J Biol Chem. 2002;277(49):47044-47051.

101. Bartness TJ, Vaughan CH, Song CK. Sympathetic and sensory innervation of brown adipose tissue. Int J Obes. 2010;34 Suppl 1:S36-S42.

102. Vaughan $\mathrm{CH}$, Bartness TJ. Anterograde transneuronal viral tract tracing reveals central sensory circuits from brown fat and sensory denervation alters its thermogenic responses. Am J Physiol Regul Integr Comp Physiol. 2012;302(9):R1049-R1058.

103. Osaka T, Kobayashi A, Namba Y, et al. Temperature- and capsaicinsensitive nerve fibers in brown adipose tissue attenuate thermogenesis in the rat. Pflugers Arch. 1998;437(1):36-42.

104. Szentirmai LKÉ. Brown adipose tissue at the intersection of sleep and temperature regulation. Temperature. 2014;1(1):16-17.

105. Martinez D, Vasconcellos LF, de Oliveira PG, Konrad SP. Weight loss and brown adipose tissue reduction in rat model of sleep apnea Lipids Health Dis. 2008;7:26.

106. Fiori CZ, Martinez D, Baronio D, et al. Downregulation of uncoupling protein-1 mRNA expression and hypoadiponectinemia in a mouse model of sleep apnea. Sleep Breath. 2014;18(3):541-548.

107. Hara J, Yanagisawa M, Sakurai T. Difference in obesity phenotype between orexin-knockout mice and orexin neuron-deficient mice with same genetic background and environmental conditions. Neurosci Lett. 2005;380(3):239-242.

108. Kok SW, Overeem S, Visscher TL, et al. Hypocretin deficiency in narcoleptic humans is associated with abdominal obesity. Obes Res. 2003;11(9):1147-1154.

109. Mochizuki T, Klerman EB, Sakurai T, Scammell TE. Elevated body temperature during sleep in orexin knockout mice. Am J Physiol Regul Integr Comp Physiol. 2006;291(3):R533-R540.

110. Feldmann HM, Golozoubova V, Cannon B, Nedergaard J. UCP1 ablation induces obesity and abolishes diet-induced thermogenesis in mice exempt from thermal stress by living at thermoneutrality. Cell Metab. 2009;9(2):203-209.
111. Tupone D, Madden CJ, Cano G, Morrison SF. An orexinergic projection from perifornical hypothalamus to raphe pallidus increases rat brown adipose tissue thermogenesis. J Neurosci. 2011;31(44): 15944-15955.

112. Yoshimatsu H, Egawa M, Bray GA. Effects of cholecystokinin on sympathetic activity to interscapular brown adipose tissue. Brain Res. 1992;597(2):298-303.

113. Elias CF, Aschkenasi C, Lee C, et al. Leptin differentially regulates NPY and POMC neurons projecting to the lateral hypothalamic area. Neuron. 1999;23(4):775-786.

114. Leproult R, Van Cauter E. Role of sleep and sleep loss in hormonal release and metabolism. Endocr Dev. 2010;17:11-21.

115. Van Cauter E, Holmback U, Knutson K, et al. Impact of sleep and sleep loss on neuroendocrine and metabolic function. Hormone Res. 2007;67 Suppl 1:2-9.

116. Yasuda T, Masaki T, Kakuma T, et al. Dual regulatory effects of orexins on sympathetic nerve activity innervating brown adipose tissue in rats. Endocrinology. 2005;146(6):2744-2748.

117. Egawa M, Yoshimatsu H, Bray GA. Preoptic area injection of corticotropin-releasing hormone stimulates sympathetic activity. Am J Physiol. 1990;259(4 Pt 2):R799-R806.

118. Egawa M, Yoshimatsu H, Bray GA. Neuropeptide Y suppresses sympathetic activity to interscapular brown adipose tissue in rats. Am J Physiol. 1991;260(2 Pt 2):R328-R334.

119. Van Cauter E, Plat L, Copinschi G. Interrelations between sleep and the somatotropic axis. Sleep. 1998;21(6):553-566.

120. Badman MK, Flier JS. The gut and energy balance: visceral allies in the obesity wars. Science. 2005;307(5717):1909-1914.

121. Batterham RL, Cohen MA, Ellis SM, et al. Inhibition of food intake in obese subjects by peptide YY3-36. New Engl J Med. 2003;349(10): 941-948.

122. Benedict C, Brooks SJ, O’Daly OG, et al. Acute sleep deprivation enhances the brain's response to hedonic food stimuli: an fMRI study. $J$ Clin Endocrinol Metab. 2012;97(3):E443-E447.

123. Naismith SL, Hickie IB, Terpening Z, et al. Circadian misalignment and sleep disruption in mild cognitive impairment. J Alzheimer's Dis. 2014;38(4):857-866.

124. Wright KP Jr, Hull JT, Hughes RJ, Ronda JM, Czeisler CA. Sleep and wakefulness out of phase with internal biological time impairs learning in humans. J Cogn Neurosci. 2006;18(4):508-521.

125. Gill S, Le HD, Melkani GC, Panda S. Time-restricted feeding attenuates age-related cardiac decline in Drosophila. Science. 2015; 347(6227):1265-1269

126. Schmid SM, Hallschmid M, Jauch-Chara K, Born J, Schultes B. A single night of sleep deprivation increases ghrelin levels and feelings of hunger in normal-weight healthy men. J Sleep Res. 2008;17(3): 331-334.

127. Mirescu C, Peters JD, Noiman L, Gould E. Sleep deprivation inhibits adult neurogenesis in the hippocampus by elevating glucocorticoids. Proc Natl Acad Sci U S A. 2006;103(50):19170-19175.

128. Backhaus J, Junghanns K, Born J, Hohaus K, Faasch F, Hohagen F. Impaired declarative memory consolidation during sleep in patients with primary insomnia: Influence of sleep architecture and nocturnal cortisol release. BiolPsychiatry. 2006;60(12):1324-1330.

129. Chang AM, Aeschbach D, Duffy JF, Czeisler CA. Evening use of lightemitting eReaders negatively affects sleep, circadian timing, and nextmorning alertness. Proc Natl Acad Sci U S A. 2015;112(4):1232-1237.

130. Robeva R, Kirilov G, Tomova A, Kumanov P. Melatonin-insulin interactions in patients with metabolic syndrome. J Pineal Res. 2008;44(1):52-56.

131. Nishida S. Metabolic effects of melatonin on oxidative stress and diabetes mellitus. Endocrine. 2005;27(2):131-136.

132. Vinogradova I, Anisimov V. Melatonin prevents the development of the metabolic syndrome in male rats exposed to different light/dark regimens. Biogerontology. 2013;14(4):401-409.

133. Pandi-Perumal SR, Srinivasan V, Spence DW, et al. Ramelteon: a review of its therapeutic potential in sleep disorders. Adv Ther. 2009;26(6):613-626. 
134. Xu TR, Yang Y, Ward R, Gao L, Liu Y. Orexin receptors: multifunctional therapeutic targets for sleeping disorders, eating disorders, drug addiction, cancers and other physiological disorders. Cell Signal. 2013;25(12):2413-2423.

135. Winrow CJ, Renger JJ. Discovery and development of orexin receptor antagonists as therapeutics for insomnia. Br J Pharmacol. 2014;171(2):283-293.

136. Roecker AJ, Cox CD, Coleman PJ. Orexin receptor antagonists: new therapeutic agents for the treatment of insomnia. J Med Chem. Epub 2015 September 15.

137. Castaneda TR, Jurgens H, Wiedmer P, et al. Obesity and the neuroendocrine control of energy homeostasis: the role of spontaneous locomotor activity. J Nutr. 2005;135(5):1314-1319.

138. Szentirmai E, Krueger JM. Obestatin alters sleep in rats. Neurosci Lett. 2006;404(1-2):222-226.

139. Zhang JV, Ren PG, Avsian-Kretchmer O, et al. Obestatin, a peptide encoded by the ghrelin gene, opposes ghrelin's effects on food intake. Science. 2005;310(5750):996-999.

140. Shemyakin A, Kapas L. L-364,718, a cholecystokinin-A receptor antagonist, suppresses feeding-induced sleep in rats. Am J Physiol Regul Integr Comp Physiol. 2001;280(5):R1420-R1426.

141. Little TJ, Horowitz M, Feinle-Bisset C. Role of cholecystokinin in appetite control and body weight regulation. Obes Rev. 2005;6(4):297-306.

142. Benedict C, Barclay JL, Ott V, Oster H, Hallschmid M. Acute sleep deprivation delays the glucagon-like peptide 1 peak response to breakfast in healthy men. Nutr Diabetes. 2013;3:e78.

143. Madsbad S. The role of glucagon-like peptide-1 impairment in obesity and potential therapeutic implications. DiabObes Metab. 2014;16(1):9-21.

144. Karra E, Chandarana K, Batterham RL. The role of peptide YY in appetite regulation and obesity. J Physiol. 2009;587(Pt 1):19-25.

145. Ahnaou A, Drinkenburg WH. Neuromedin U(2) receptor signaling mediates alteration of sleep-wake architecture in rats. Neuropeptides. 2011;45(2):165-174.

146. Held K, Antonijevic I, Murck H, Kuenzel H, Steiger A. NeuropeptideY (NPY) shortens sleep latency but does not suppress ACTH and cortisol in depressed patients and normal controls. Psychoneuroendocrinology. 2006;31(1):100-107.

147. Antonijevic IA, Murck H, Bohlhalter S, Frieboes RM, Holsboer F, Steiger A. Neuropeptide Y promotes sleep and inhibits ACTH and cortisol release in young men. Neuropharmacology. 2000;39(8):1474-1481.

148. Dyzma M, Boudjeltia KZ, Faraut B, Kerkhofs M. Neuropeptide Y and sleep. Sleep Med Rev. 2010;14(3):161-165.
149. Adamantidis A, de Lecea L. Sleep and metabolism: shared circuits, new connections. Trends Endocrinol Metab. 2008;19(10): 362-370.

150. Romanova IV, Mikhrina AL. [Participation of Agouti related peptide in machanisms of wakefulness-sleep cycle regulation]. Fiziol Chel. 2013;39(6):24-30.

151. Chastrette N, Cespuglio R. Influence of proopiomelanocortinderived peptides on the sleep-waking cycle of the rat. Neurosci Lett. 1985;62(3):365-370.

152. Chastrette N, Cespuglio R, Jouvet M. Proopiomelanocortin (POMC)derived peptides and sleep in the rat. Part 1 - Hypnogenic properties of ACTH derivatives. Neuropeptides. 1990;15(2):61-74.

153. Mieda M, Hasegawa E, Kisanuki YY, Sinton CM, Yanagisawa M, Sakurai T. Differential roles of orexin receptor-1 and -2 in the regulation of non-REM and REM sleep. J Neurosci. 2011;31(17): 6518-6526.

154. Willie JT, Chemelli RM, Sinton CM, Yanagisawa M. To eat or to sleep? Orexin in the regulation of feeding and wakefulness. Annu Rev Neurosci. 2001;24:429-458.

155. Zhang X, van den Pol AN. Thyrotropin-releasing hormone (TRH) inhibits melanin-concentrating hormone neurons: implications for TRH-mediated anorexic and arousal actions. J Neurosci. 2012;32(9):3032-3043.

156. Uchida M, Suzuki M, Shimizu K. Effects of urocortin, corticotropinreleasing factor (CRF) receptor agonist, and astressin, CRF receptor antagonist, on the sleep-wake pattern: analysis by radiotelemetry in conscious rats. Biol Pharm Bull. 2007;30(10):1895-1897.

157. Stengel A, Tache Y. CRF and urocortin peptides as modulators of energy balance and feeding behavior during stress. Front Neurosci. 2014;8:52.

158. Konadhode RR, Pelluru D, Shiromani PJ. Neurons containing orexin or melanin concentrating hormone reciprocally regulate wake and sleep. Front Syst Neurosci. 2014;8:244.

159. Steiger A. Sleep and the hypothalamo-pituitary-adrenocortical system. Sleep Med Rev. 2002;6(2):125-138.

160. Richard D, Huang Q, Timofeeva E. The corticotropin-releasing hormone system in the regulation of energy balance in obesity. Int J Obes Relat Metab Disord. 2000;24 Suppl 2:S36-S39.

161. Mongrain V, Hernandez SA, Pradervand S, et al. Separating the contribution of glucocorticoids and wakefulness to the molecular and electrophysiological correlates of sleep homeostasis. Sleep. 2010;33(9):1147-1157.

162. de Kloet AD, Krause EG, Solomon MB, et al. Adipocyte glucocorticoid receptors mediate fat-to-brain signaling. Psychoneuroendocrinology. 2015;56:110-119.
Nature and Science of Sleep

\section{Publish your work in this journal}

Nature and Science of Sleep is an international, peer-reviewed, open access journal covering all aspects of sleep science and sleep medicine, including the neurophysiology and functions of sleep, the genetics of sleep, sleep and society, biological rhythms, dreaming, sleep disorders and therapy, and strategies to optimize healthy sleep. The journal welcomes

\section{Dovepress}

original research, clinical \& epidemiological studies, reviews \& evaluations, case reports and extended reports. The manuscript management system is completely online and includes a very quick and fair peerreview system, which is all easy to use. Visit http://www.dovepress.com/ testimonials.php to read real quotes from published authors. 